PULMONARY HYPERTENSION

\title{
Anti-endothelial cell antibodies in idiopathic and systemic sclerosis associated pulmonary arterial hypertension
}

\author{
M C Tamby, Y Chanseaud, M Humbert, J Fermanian, P Guilpain, P Garcia-de-la-Peña-Lefebvre, \\ S Brunet, A Servettaz, B Weill, G Simonneau, L Guillevin, M C Boissier, L Mouthon
}

Thorax 2005;60:765-772. doi: 10.1136/thx.2004.029082

See end of article for authors' affiliations

Correspondence to: Dr L Mouthon, Laboratoire d'Immunologie, Pavillon Gustave Roussy, UFR Cochin-Port Royal, 8 rue Méchain, 75014 Paris, France; luc.mouthon@cch. aphp.fr

Received 24 May 2004 Accepted 15 May 2005
Background: It has previously been shown that $\lg G$ antibodies from patients with limited cutaneous systemic sclerosis (SSc) bind to specific microvascular endothelial cell antigens. Since patients with limited cutaneous SSc are prone to develop pulmonary arterial hypertension (PAH), and since endothelial cell activation is involved in the pathogenesis of idiopathic PAH (IPAH), a study was undertaken to examine the presence of anti-endothelial cell antibodies in patients with idiopathic or SSc associated PAH.

Methods: PAH was confirmed by right heart catheterisation (mean pulmonary artery pressure at rest $>25 \mathrm{~mm} \mathrm{Hg}$ ). Serum $\lg G$ and $\lg M$ reactivities were analysed by immunoblotting on human macrovascular and microvascular lung and dermal endothelial cells from patients with IPAH $(n=35)$, patients with PAH associated with SSc $(n=10)$, patients with diffuse $(n=10)$ or limited cutaneous $(n=10)$ SSc without PAH, and 65 age and sex matched healthy individuals.

Results: IgG antibodies from patients with IPAH bound to a $36 \mathrm{kDa}$ band in macrovascular endothelial cell extracts with a higher intensity than lgG from other patient groups and controls. IgG antibodies from patients with IPAH bound more strongly to a $58 \mathrm{kDa}$ band in microvascular dermal endothelial cells and to a $53 \mathrm{kDa}$ band in microvascular lung endothelial cells than $\lg G$ antibodies from other patients and controls. IgG antibodies from patients with limited cutaneous SSc with or without PAH, but not from other groups or from healthy controls, bound to two major bands (75 kDa and $85 \mathrm{kDa}$ ) in microvascular endothelial cells.

Conclusion: IgG antibodies from patients with idiopathic or SSc associated PAH express distinct reactivity profiles with macrovascular and microvascular endothelial cell antigens.
$\mathrm{P}$ ulmonary arterial hypertension (PAH) is a rare disease with an incidence rate of one per million in the general population which represents a major cause of progressive right sided heart failure leading to premature death. ${ }^{1}$ It is defined by increased mean pulmonary artery pressure above $25 \mathrm{~mm} \mathrm{Hg}$ at rest resulting from chronic obstruction of small pulmonary arteries caused by endothelial and vascular smooth muscle cell dysfunction and proliferation. ${ }^{2}$

PAH may be idiopathic (IPAH) — either sporadic, familial, or associated with dexfenfluramine therapy. ${ }^{1}$ It may also be associated with connective tissue diseases such as systemic sclerosis (SSc), ${ }^{3}$ mixed connective tissue diseases, and systemic lupus erythematosus. Approximately 14\% of SSc patients develop PAH, which is responsible for a high mortality rate. ${ }^{3}$

The recent identification of germline mutations of genes coding for members of the transforming growth factor $\beta$ (TGF- $\beta$ ) receptor family, the bone morphogenetic protein receptor type II (BMPR-II) in sporadic and familial PAH, focused much attention on the role of cytokines and growth factors in these disorders. ${ }^{45}$ However, no BMPR-II mutations have been detected in patients with SSc, suggesting that other mechanisms could be involved in PAH associated with SSc. ${ }^{6}$ Indeed, in addition to abnormal TGF- $\beta$ signalling, altered expression and production of several cytokines and growth factors have been found in severe $\mathrm{PAH}$, highlighting the possible influence of inflammatory mechanisms in this condition. $^{2}$ Furthermore, the prevalence of anti-endothelial cell antibodies (AECA) in patients with SSc varies from $44 \%$ to $84 \% .^{7-9}$ Several studies have indicated that AECA are associated with a higher incidence of vascular manifestations. ${ }^{910}$ We have previously defined more precisely the specificities of those antibodies. IgG AECA from patients with diffuse SSc are common to microvascular and macrovascular endothelial cells and correspond to topoisomerase 1, whereas IgG from patients with limited cutaneous SSc bind to an $80 \mathrm{kDa}$ protein band in microvascular endothelial cells only. ${ }^{11}$ Since the activation of endothelial cells mediated by AECA can be involved in the pathogenesis of PAH in patients with SSc, we analysed the activities of AECA in patients with PAH associated with SSc and in patients with IPAH.

\section{METHODS \\ Patients}

Patients were screened by Doppler echocardiography and $\mathrm{PAH}$ was defined as systolic pulmonary artery pressure $>40 \mathrm{~mm} \mathrm{Hg}$. PAH, confirmed by right heart catheterisation in all patients, was defined as mean pulmonary artery pressure at rest $>25 \mathrm{~mm} \mathrm{Hg}$. Sixty five patients were included in the study, comprising 35 with IPAH (20 with sporadic PAH, 10 with dexfenfluramine associated PAH, and five with familial PAH), 10 with SSc associated PAH (SSc$\mathrm{PAH}), 10$ with limited cutaneous SSc without PAH, and 10 with diffuse SSc without PAH. Patients with limited cutaneous and diffuse SSc fulfilled the criteria of LeRoy and Medsger ${ }^{12}$ and the American Rheumatism Association, ${ }^{13}$ respectively. Disease duration was significantly longer in SSc patients than in patients with IPAH (table 1). All patients

Abbreviations: AECA, anti-endothelial cell antibodies; BMPR-II, bone morphogenetic protein receptor type II; HUVEC, human umbilical vein endothelial cells; HMVEC-d, human microvascular dermal endothelial cells; HMVEC-I, human microvascular lung endothelial cells; IPAH, idiopathic pulmonary arterial hypertension; $\mathrm{PAH}$, pulmonary arterial hypertension; SSc, systemic sclerosis 
Table 1 Clinical and immunological characteristics of patients with IPAH and those with SSc with or without PAH

\begin{tabular}{|c|c|c|c|c|c|c|c|}
\hline Patient group & $\begin{array}{l}\text { No of } \\
\text { patients } \\
\text { (M/F) }\end{array}$ & $\begin{array}{l}\text { Mean (SD) } \\
\text { age } \\
\text { (years) }\end{array}$ & $\begin{array}{l}\text { Mean (SD) lgG and } \\
\operatorname{lgM} \text { concentrations } \\
(\mathrm{mg} / \mathrm{ml})\end{array}$ & $\begin{array}{l}\text { Autoantibodies } \\
\text { (ANA, ACA, anti-topo 1) }\end{array}$ & $\begin{array}{l}\text { Mean (SD) } \\
\text { disease duration } \\
\text { (months) }\end{array}$ & $\begin{array}{l}\text { Mean (SD) } \\
\text { PAP } \\
\text { (mm Hg) }\end{array}$ & Treatments \\
\hline IPAH & $35(9 / 26)$ & $44.9(15.5)$ & $\begin{array}{l}\lg G: 9.99(3.19) \\
\lg M: 1.12(0.63)\end{array}$ & $\begin{array}{l}\mathrm{ANA}=3 / 35(9 \%) \\
\mathrm{ACA}=0 \\
\text { Anti-topo } 1=0\end{array}$ & $16(21.5)$ & 61.4 (16.2)‡ & $\begin{array}{l}\text { Epoprostenol: } 13 \\
\text { Oral anticoagulant: } 22\end{array}$ \\
\hline SSc with PAH & $10(4 / 6)$ & $58.4(11)$ & $\begin{array}{l}\lg G: 12.8(3.25) \\
\lg M: 2.3(2.46)\end{array}$ & $\begin{array}{l}A N A=5 / 10(50 \%) \\
A C A=3 / 10(30 \%) \\
\text { Anti-topo } 1=2 / 10(20 \%)\end{array}$ & $\begin{array}{l}128(99)^{*} \\
19(19.9) \dagger\end{array}$ & 50.1 (13.3)‡ & $\begin{array}{l}\text { Epoprostenol: } 4 \\
\text { Oral anticoagulant: } 4\end{array}$ \\
\hline $\begin{array}{l}\text { Limited cutaneous } \\
\text { SSc without PAH }\end{array}$ & $10(1 / 9)$ & $44.8(15.6)$ & $\begin{array}{l}\text { lgG: } 11.5(3.48) \\
\lg M: 1.79(0.69)\end{array}$ & $\begin{array}{l}A N A=10 / 10(100 \%) \\
A C A=10 / 10(100 \%)\end{array}$ & $58(58)$ & $\S$ & $\begin{array}{l}\text { No epoprostenol } \\
\text { or anticoagulant }\end{array}$ \\
\hline $\begin{array}{l}\text { Diffuse SSc without } \\
\text { PAH }\end{array}$ & $10(4 / 6)$ & $50.2(11)$ & $\begin{array}{l}\text { lgG: } 13.6(3.17) \\
\lg M: 1.85(1.14)\end{array}$ & $\begin{array}{l}\text { ANA }=10 / 10(100 \%) \\
\text { ACA }=0 \\
\text { Anti-topo } 1=7 / 10(70 \%)\end{array}$ & $98(116)$ & $\S$ & $\begin{array}{l}\text { No epoprostenol } \\
\text { or anticoagulant }\end{array}$ \\
\hline \multicolumn{8}{|c|}{$\begin{array}{l}\text { IPAH, idiopathic pulmonary arterial hypertension; SSc, systemic } \\
\text { antibodies; ACA, anti-centromere antibodies; anti-topo 1, anti-tc } \\
\text { *Disease duration of SSc. } \\
\text { TDisease duration of PAH. } \\
\text { †Mean PAP as measured by right heart catheterisation. } \\
\text { §Systolic PAP }<35 \mathrm{~mm} \mathrm{Hg} \text { as measured by echocardiography. }\end{array}$} \\
\hline
\end{tabular}

with diffuse SSc without PAH had interstitial lung disease as assessed by chest high resolution computed tomodensitometry and a vital capacity $<80 \%$ of predicted values and/or a gas transfer factor of $<75 \%$ of predicted values. None of the patients was receiving corticosteroids or immunosuppressants and none had cancer or other connective tissue disease. Sixty five unrelated age and sex matched healthy donors were studied as controls. All patients gave their written informed consent.

\section{Ig sources}

Serum samples from all patients and healthy controls were aliquoted and stored at $-80^{\circ} \mathrm{C}$ until tested. IgG and $\operatorname{IgM}$ antibody concentrations, determined by nephelometry, did not differ significantly (table 1). Three of the $35 \mathrm{IPAH}$ patients had low titres of antinuclear antibodies, whereas five of 10 patients with SSc with PAH and all the patients with SSc without PAH had antinuclear antibodies. A therapeutic preparation of normal human IgG, intravenous immunoglobulin, IVIg (Tegeline, Laboratoire du Fractionnement Biologique et des Biotechnologies (LFB), Les Ulis, France) and normal human polyclonal IgM (LFB) served as internal standards.

\section{Cell culture}

Human umbilical vein endothelial cells (HUVEC) were obtained by digestion of umbilical cords with $0.1 \%$ collagenase (Sigma, St Louis, MO, USA) as described previously. ${ }^{14}$ They were cultured in 199 Earle's salts and HEPES medium (Life Technologies Ltd, Auckland, NZ) supplemented with $20 \%$ heat inactivated fetal calf serum (FCS), $2 \mathrm{mM} \mathrm{L-}$ glutamine, $100 \mathrm{U} / \mathrm{ml}$ penicillin, $100 \mu \mathrm{g} / \mathrm{ml}$ streptomycin, and $0.25 \mu \mathrm{g} / \mathrm{ml}$ amphotericin $\mathrm{B}$ at $37^{\circ} \mathrm{C}$ in $5 \% \mathrm{CO}_{2}$. When confluent, the cells were detached using $0.05 \%$ trypsin, $2 \mu \mathrm{M}$ EDTA. After the third passage a HUVEC protein extract was prepared. Human microvascular dermal endothelial cells (HMVEC-d) and human microvascular lung endothelial cells (HMVEC-1) were purchased from Clonetics Corporation (San Diego, CA, USA) after four passages. They were cultured with microvascular endothelial cell growth medium containing 5\% FCS, $0.04 \%$ hydrocortisone, $0.1 \%$ vascular endothelial growth factor, $0.1 \%$ human recombinant insulin-like growth factor 1 , $0.4 \%$ ascorbic acid, $0.1 \%$ human epidermal growth factor, and $0.1 \%$ GA-1000 (gentamicin sulfate and amphotericin B) (EGM-2-MV Bulletkit, Clonetics Corporation). The endothelial cell phenotype of the three types of cultured cells was confirmed by their typical growth in cobblestone monolayers and labelling of von Willebrand factor by a specific polyclonal rabbit antibody (Dako, Glostrup, Denmark).

\section{Detection of antibody reactivities with nuclear antigens}

Anti-centromere and anti-topoisomerase 1 antibodies were detected by indirect immunofluorescence on HEp-2 cells and double immunodiffusion in agar against calf thymus extract, respectively.

\section{Detection of antibody reactivities with cell antigens}

Antibody reactivities were analysed using a semi-quantitative immunoblotting technique with normal human endothelial cells and HEp-2 cells. Cellular protein extracts were performed in a buffer containing 4\% SDS, $1.45 \mathrm{M} 2$ mercaptoethanol, $125 \mathrm{mM}$ Tris/HCl pH 6.8, $1 \mu \mathrm{g} / \mathrm{ml}$ aprotinin, $1 \mu \mathrm{g} / \mathrm{ml}$ pepstatin, and $1 \mu \mathrm{g} / \mathrm{ml}$ leupeptin and then sonicated $4 \times 30 \mathrm{~s}$. Equal amounts of solubilised proteins were subjected to preparative SDS-polyacrylamide gel electrophoresis (PAGE) through $10 \%$ polyacrylamide gels. The proteins were then transferred onto nitrocellulose membrane for 1 hour at $0.8 \mathrm{~mA} / \mathrm{cm}^{2}$ using a semi-dry electroblotter model A (Ancos, Hojby, Denmark). After blocking with PBS-0.2\%

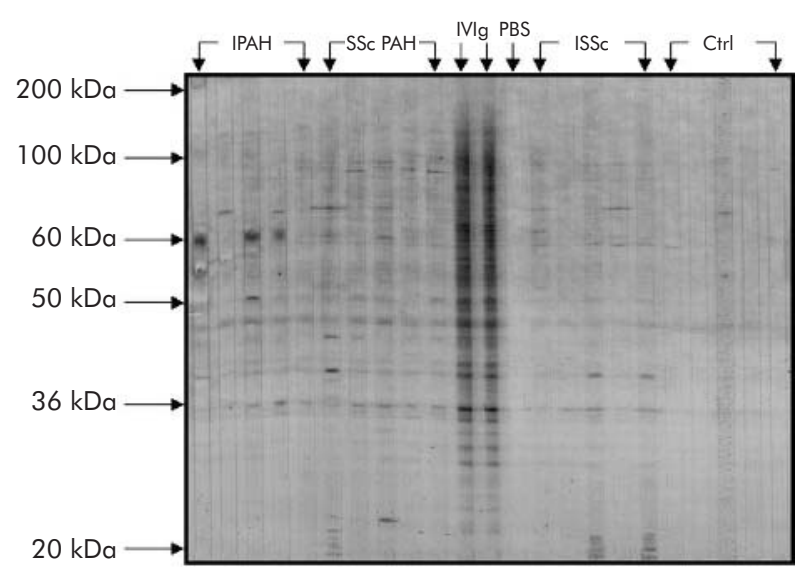

Figure 1 Western blotting of $\lg G$ with protein extracts of human umbilical vein endothelial cells (HUVEC). Serum IgG from patients with IPAH, SSc-PAH, limited cutaneous SSc without PAH, and age and sex matched healthy controls was immunoblotted at $200 \mu \mathrm{g} / \mathrm{ml}$ with a soluble extract of HUVEC. Normal human polyclonal lgG (intravenous immunoglobulins) and secondary anti-Fc $\gamma$ antibody tested alone were used as positive and negative controls, respectively. 
Tween for 90 minutes, the membranes were incubated with serum samples for 4 hours at room temperature at $200 \mu \mathrm{g} / \mathrm{ml}$ IgG or $20 \mu \mathrm{g} / \mathrm{ml}$ IgM in a Cassette Miniblot System (Immunetics Inc, Cambridge, MA, USA). They were then extensively washed before being incubated with either secondary rabbit anti-human Fc $\gamma$ or Fc $\mu$ antibody coupled to alkaline phosphatase (Dako) for 90 minutes at room temperature. Immunoreactivities were revealed using the nitroblue tetrazolium/5-bromo-4-chloro-3-indolyl-phosphate (NBT/BCIP) substrate (Sigma). Immunoreactivities were quantified by scanning the membranes with a densitometer (Epson Perfection 1200S, Seiko Epson Corporation, NaganoKen, Japan). The membranes were then stained with colloidal gold (Protogold, Biocell, Cardiff, UK) and subjected to a second densitometric analysis to quantify transferred proteins. This approach allows the immunoreactivity repertoires to be compared by referring to their respective protein peaks corrected for electrophoretic migration defects by superimposing corresponding protein peaks by means of computer analysis. Standard IgM or IgG preparations were included in each blot to allow the rescaling of the membranes transferred with a given protein extract and to adjust for the intensity of labelling on different membranes. ${ }^{11}{ }^{14}$ All experiments were performed twice.

\section{Statistical analyses}

Because of the large number of reactivities identified in the blots, the data were submitted to multivariate statistical analysis using IGOR software (Igor Pro 3.16, Wavemetrics Inc, Lake Oswego, OR, USA) with specially designed packages and Systat software (Version 11.0, Systat Software, Point Richmond, CA, USA). Densitometry curves of IgG and IgM reactivities of each patient and control were divided into sections surrounding individual peaks of immunoreactivity on each substrate; 8-10 sections were selected, depending on the protein extract used and number of antibody reactivities identified in the blots. The number of comparisons performed was limited on the basis of clinical relevance and five comparisons were performed for IgG and for IgM reactivities: PAH patients $v$ healthy controls; IPAH patients $v$ healthy controls; IPAH patients $v$ SSc-PAH; SSc$\mathrm{PAH} v$ SSc patients without PAH; and SSc-PAH patients $v$ healthy individuals. In order to compare groups of individuals (groups of patients two by two and patients $v$ controls), for each comparison we calculated the factor scores of each of the subjects after performing factor analysis of the whole data of patients and healthy controls. Factor analysis was performed using the principal component analysis as a method of extraction and factors with eigenvalues $>1$ were retained. ${ }^{15}$ Independent factors were obtained using the varimax rotation method. Factor scores of each of the individuals for the retained factors were submitted either to a paired Wilcoxon test to compare the patterns of reactivity of patients to age and sex matched healthy controls, or to a Mann-Whitney test to compare the patterns of reactivity of patients two by two. One to six protein bands made important contributions to the calculation of factors of the factor analysis. The molecular weights of the protein bands contributing to the different factors varied according to the source of antigens tested and the two groups compared.

\section{RESULTS}

\section{Serum anti-HUVEC IgG reactivities}

The patterns of reactivity of serum IgG antibodies with HUVEC antigens were generally homogeneous in healthy individuals and among patients in each group. However, IgG antibodies from a few individuals in each group bound to a unique band with a higher intensity than IgG antibodies from others. IgG from all healthy individuals and patients in each group bound
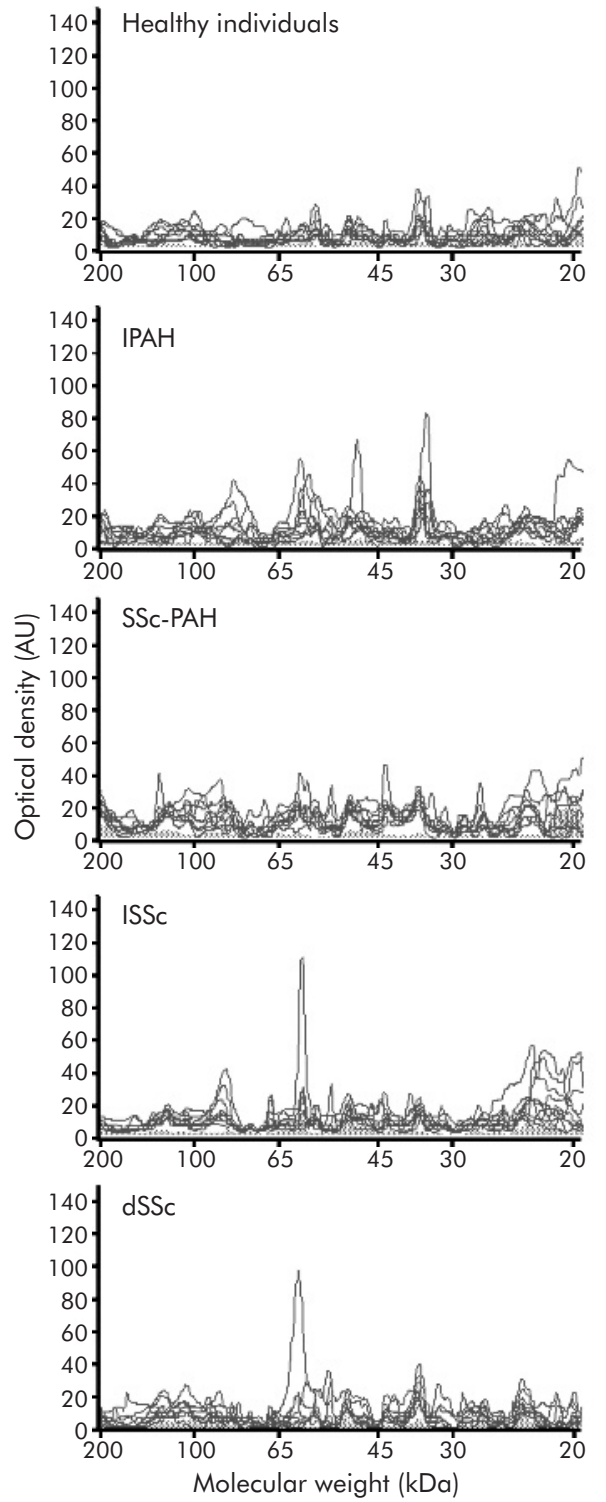

Figure 2 Densitometric profiles of $\lg G$ reactivity of 10 healthy individuals, 10 patients with IPAH, 10 with SSc-PAH, 10 with limited cutaneous SSc (ISSc) without PAH, and 10 with diffuse SSc (dSSc) without PAH with human umbilical vein endothelial cell (HUVEC) antigens. Serum samples were diluted to an $\lg G$ concentration of $200 \mu \mathrm{g} / \mathrm{ml}$. The densitometric pattern of $\mathrm{lgG}$ reactivities of each individual is depicted as a full line curve. Grey areas depict the densitometric pattern observed in the presence of the secondary anti-Fc $\gamma$ antibody alone. Molecular weights are expressed as $\mathrm{kDa}$ in the abscissa and optical densities are expressed as arbitrary units $(A U)$ in the ordinates.

to one major $36 \mathrm{kDa}$ protein band (figs 1 and 2, table 2). This band was more marked by serum IgG antibodies from patients with IPAH than by serum IgG antibodies from the other disease groups or from healthy controls (fig 2). In addition, IgG antibodies from 17 of the 35 patients with IPAH, but not from other patient groups or healthy controls, bound to a $60 \mathrm{kDa}$ protein band (fig 2, table 2).

\section{Serum anti-HMVEC-d and HMVEC-I IgG reactivities}

As observed with HUVEC, the patterns of reactivity of IgG antibodies with HMVEC-d and HMVEC-l antigens were generally homogeneous among healthy individuals and in patients with IPAH (fig 3). A $58 \mathrm{kDa}$ protein band in HMVEC-d and a $53 \mathrm{kDa}$ protein band in HMVEC-l extracts 
Table 2 Serum IgG reactivities of patients with IPAH, patients with SSc with or without PAH, and healthy individuals with endothelial and HEp-2 cell antigens

\begin{tabular}{|c|c|c|c|c|}
\hline Patient groups/antigen sources & HUVEC & HMVEC-d & HMVEC-I & HEp-2 \\
\hline \multicolumn{5}{|l|}{ Healthy individuals } \\
\hline No of reactivity peaks & 7-9 & $9-12$ & $9-12$ & $7-9$ \\
\hline \multirow[t]{5}{*}{ Main reactivity(ies) (no of individuals) } & $36 \mathrm{kDa}(51 / 65)$ & $45 \mathrm{kDa}(39 / 65)$ & $28 \mathrm{kDa}(26 / 65)$ & \\
\hline & & $58 \mathrm{kDa}(33 / 65)$ & $40 \mathrm{kDa}(52 / 65)$ & $27 \mathrm{kDa}(12 / 65)$ \\
\hline & & $63 \mathrm{kDa}(33 / 65)$ & $55 \mathrm{kDa}(49 / 65)$ & $31 \mathrm{kDa}(41 / 65)$ \\
\hline & & & 63 kDa (24/65) & $45 \mathrm{kDa}(40 / 65)$ \\
\hline & & & 77 kDa (32/65) & \\
\hline \multicolumn{5}{|l|}{ IPAH } \\
\hline No of reactivity peaks & $5-7$ & $8-10$ & $8-10$ & $7-9$ \\
\hline \multirow{5}{*}{ Main reactivities (no of patients) } & $36 \mathrm{kDa}(34 / 35)$ & $28 \mathrm{kDa}(23 / 35)$ & 28 kDa (20/35) & $27 \mathrm{kDa}(24 / 35)$ \\
\hline & $60 \mathrm{kDa}(17 / 35)$ & $45 \mathrm{kDa}(35 / 35)$ & 40 kDa (32/35) & $31 \mathrm{kDa}(33 / 35)$ \\
\hline & & $58 \mathrm{kDa}(32 / 35)$ & $53 \mathrm{kDa}(35 / 35)$ & $45 \mathrm{kDa}(20 / 35)$ \\
\hline & & $63 \mathrm{kDa}(29 / 35)$ & $68 \mathrm{kDa}(16 / 35)$ & \\
\hline & & $68 \mathrm{kDa}(17 / 35)$ & & \\
\hline \multicolumn{5}{|l|}{ SSc with PAH } \\
\hline No of reactivity peaks & $8-10$ & $8-10$ & $8-10$ & $6-8$ \\
\hline \multirow[t]{8}{*}{ Main reactivity(ies) (no of patients) } & $36 \mathrm{kDa}(10 / 10)$ & 28 kDa $(9 / 10)$ & 28 kDa $(8 / 10)$ & 31 kDa $(9 / 10)$ \\
\hline & & 45 kDa $(9 / 10)$ & 44 kDa $(8 / 10)$ & 36 kDa $(9 / 10)$ \\
\hline & & 53 kDa $(5 / 10)$ & $53 \mathrm{kDa}(7 / 10)$ & 45 kDa $(8 / 10)$ \\
\hline & & 57 kDa $(10 / 10)$ & 57 kDa $(7 / 10)$ & $58 \mathrm{kDa}(10 / 10)$ \\
\hline & & $63 \mathrm{kDa}(7 / 10)$ & 75 kDa (510) & $75 \mathrm{kDa}(4 / 10)$ \\
\hline & & $67 \mathrm{kDa}(10 / 10)$ & 85 kDa $(6 / 10)$ & \\
\hline & & $75 \mathrm{kDa}(8 / 10)$ & & \\
\hline & & $85 \mathrm{kDa} / 6 / 10$ & & \\
\hline \multicolumn{5}{|l|}{ Limited cutaneous SSc without PAH } \\
\hline No of reactivity peaks & $6-8$ & $4-6$ & $8-12$ & $8-10$ \\
\hline \multirow[t]{6}{*}{ Main reactivities (no of patients) } & 36 kDa $(9 / 10)$ & 45 kDa $(6 / 10)$ & $40 \mathrm{kDa}(8 / 10)$ & 31 kDa $(7 / 10)$ \\
\hline & 80 kDa $(6 / 10)$ & $75 \mathrm{kDa}(10 / 10)$ & $55 \mathrm{kDa}(10 / 10)$ & $45 \mathrm{kDa}(8 / 10)$ \\
\hline & & $85 \mathrm{kDa}(810)$ & $70 \mathrm{kDa}(7 / 10)$ & 75 kDa (8/10) \\
\hline & & & 75 kDa $(8 / 10)$ & 85 kDa $(5 / 10)$ \\
\hline & & & 85 kDa $(9 / 10)$ & \\
\hline & & & 165 kDa $(7 / 10)$ & \\
\hline \multicolumn{5}{|l|}{ Diffuse SSc without PAH } \\
\hline No of reactivity peaks & $6-8$ & $7-9$ & $10-12$ & $6-9$ \\
\hline \multirow[t]{5}{*}{ Main reactivity(ies) (no of patients) } & $36 \mathrm{kDa}(10 / 10)$ & 45 kDa $(8 / 10)$ & 43 kDa $(7 / 10)$ & 31 kDa $(8 / 20)$ \\
\hline & & $50 \mathrm{kDa}(4 / 10)$ & $45 \mathrm{kDa}(5 / 10)$ & $45 \mathrm{kDa}(7 / 10)$ \\
\hline & & 75 kDa $(6 / 10)$ & 55 kDa $(7 / 10)$ & $100 \mathrm{kDa}(6 / 10)$ \\
\hline & & $100 \mathrm{kDa}(6 / 10)$ & $70 \mathrm{kDa}(7 / 10)$ & \\
\hline & & & $100 \mathrm{kDa}(6 / 10)$ & \\
\hline
\end{tabular}

IPAH, idiopathic pulmonary arterial hypertension; SSc, systemic sclerosis; HUVEC, human umbilical vein endothelial cells; HMVEC-d, human microvascular dermal endothelial cells; HMVEC-I, human microvascular lung endothelial cells; kDa, kiloDalton.

were more intensely revealed by IgG antibodies from IPAH patients than by IgG antibodies from controls and patients in other groups. IgG antibodies from SSc-PAH patients and from patients with limited cutaneous SSc without PAH bound to two major protein bands of 75 and $85 \mathrm{kDa}$ that were not recognised by IgG antibodies from other patients or healthy controls. Finally, IgG antibodies from patients with diffuse SSc without PAH bound to a $100 \mathrm{kDa}$ protein band that was not recognised by IgG antibodies from healthy individuals and other patients.

\section{Serum anti-HEp- 2 cell $\lg G$ reactivities}

In order to document the endothelial cell specificity of IgG reactivities, additional experiments were performed using a protein extract of HEp-2 cells, a reference substrate for the identification of antinuclear antibodies. Healthy individuals and patients with IPAH expressed a low number of reactivities, with one major IgG reactivity directed toward a $45 \mathrm{kDa}$ protein band (table 2). In contrast, SSc patients in the different groups expressed a large number of IgG reactivities with two major protein bands of 75 and $85 \mathrm{kDa}$ in SSc-PAH patients and those with limited cutaneous SSc without PAH, and one major protein band of $100 \mathrm{kDa}$ in patients with diffuse SSc (table 2 and fig S1 available online only at http:// www.thoraxjnl.com/supplemental)

\section{Comparison of factor scores of serum anti-endothelial} cell and anti-HEp-2 cell IgG reactivities

Patients with PAH (IPAH and SSc-PAH) differed significantly from healthy individuals for IgG reactivity with HMVEC-l and HMVEC-d and HEp-2 cell extracts, with the exception of factor 2 (75 and $77 \mathrm{kDa}$ ) on HMVEC-l, factor 3 on HEp-2 cells, and HUVEC for all factors (table 3). Interestingly, serum IgG from SSc-PAH patients did not differ from those of healthy controls, with the exception of factor 3 of the factor analysis on HEp-2 cells which corresponded to reactivities at $28 \mathrm{kDa}$ and $45 \mathrm{kDa}$ (table 3 ).

IgG reactivities from SSc-PAH patients were compared with those of patients with IPAH and those of patients with SSc without PAH. No significant difference was found between IPAH and SSc-PAH patients for IgG reactivities with the different sources of antigens tested, with the exception of factor 4 on HMVEC-d and factor 2 on HEp-2 cells, with a $58 \mathrm{kDa}$ band contributing to both factors (table 4). No significant difference was found between SSc$\mathrm{PAH}$ patients and SSc patients without $\mathrm{PAH}$ for reactivity 

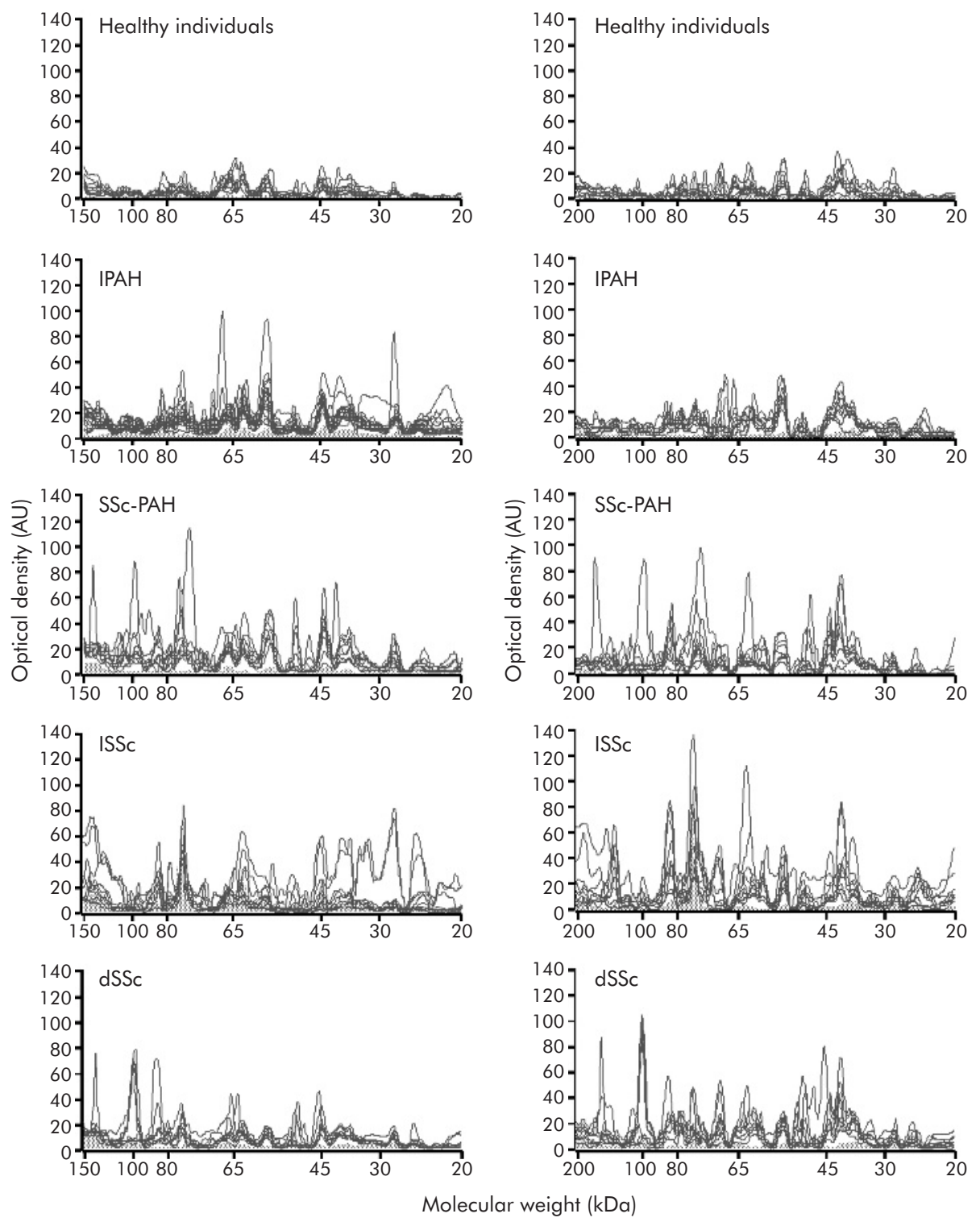

Figure 3 Densitometric profiles of $\lg G$ reactivity of 10 healthy individuals, 10 patients with IPAH, 10 with SSc-PAH, 10 with limited cutaneous SSc (ISSc) without PAH, and 10 with diffuse SSc (dSSc) without PAH with HMVEC-d (left panels) and HMVEC-I (right panels) antigens. Serum samples were diluted to an $\mathrm{lg} G$ concentration of $200 \mu \mathrm{g} / \mathrm{ml}$. The densitometric pattern of the $\lg G$ reactivities of each individual is depicted as a full line curve. Grey areas depict the densitometric pattern observed in the presence of the secondary anti-Fcy antibody alone. Molecular weights are expressed as $\mathrm{kDa}$ in the abscissa and optical densities are expressed as arbitrary units (AU) in the ordinates.

with the different sources of antigens tested, with the exception of factor 1 on HMVEC-d (table 4).

\section{Serum anti-endothelial cell IgM reactivities}

IgM reactivity patterns with HUVEC antigens were relatively homogeneous among healthy individuals, IPAH patients, and those with limited cutaneous SSc and diffuse SSc, with 5-7 reactivities including one major reactivity directed toward a $55 \mathrm{kDa}$ protein band (table 5). IgM from healthy individuals and patients with diffuse SSc without PAH bound to 9-12 protein bands in HMVEC-1 and HMVEC-d protein extracts, including one major reactivity directed towards a $65 \mathrm{kDa}$ protein band (table 5). IgM from IPAH patients, SSc-PAH patients, and patients with limited cutaneous SSc without PAH strongly bound to two additional major protein bands of 32 and $48 \mathrm{kDa}$ (table 5), whereas IgM from other patients and controls bound to those bands with low intensity. Similar results to those obtained with HMVEC-l antigens were obtained when testing IgM reactivity patterns of patients and controls against HMVEC-d antigens (fig S2, available online only at http:// www.thoraxjnl.com/supplemental).

\section{Comparison of factor scores of serum anti-endothelial} cell and anti-HEp-2 cell IgM reactivities

IgM reactivities of patients in each group did not differ from those of controls for reactivity with all sources of antigens tested with the exceptions of patients with PAH on factors 2 (63, $68 \mathrm{kDa})$ and 3 (130 kDa) and SSc-PAH patients on factor 1 on HUVEC antigens (table 3). IgM reactivities from patients in the different groups were then compared two by two. IgM reactivities from SSc patients with PAH and SSc patients without PAH did not differ significantly except for factor 3 of the factor analysis on HUVEC (table 4). A $130 \mathrm{kDa}$ peak contributed the most to this factor. IgM reactivities from IPAH patients and SSc patients with PAH did not differ significantly, whatever the source of antigens tested (table 4). 
Table 3 Comparison of factor scores of serum anti-endothelial and anti-HEp-2 cell lgG and lgM reactivities from patients with $\mathrm{PAH}$ and their respective controls

\begin{tabular}{|c|c|c|c|c|c|c|c|}
\hline \multirow[b]{2}{*}{$\begin{array}{l}\text { Antigen } \\
\text { source }\end{array}$} & \multirow[b]{2}{*}{ Isotype } & \multicolumn{2}{|l|}{ PAH } & \multicolumn{2}{|l|}{ IPAH } & \multicolumn{2}{|l|}{ SSc-PAH } \\
\hline & & $\begin{array}{l}\text { MW of bands } \\
\text { contributing to factors } \\
\text { (kDa) }\end{array}$ & $\mathrm{p}$ value & $\begin{array}{l}\text { MW of bands } \\
\text { contributing to factors } \\
\text { (kDa) }\end{array}$ & $\mathrm{p}$ value & $\begin{array}{l}\text { MW of bands } \\
\text { contributing to factors } \\
\text { (kDa) }\end{array}$ & $\mathrm{p}$ value \\
\hline \multirow[t]{7}{*}{ HUVEC } & \multirow[t]{4}{*}{$\lg G$} & Factor $1: 32,50-60$ & Factor 1: 0.89 & Factor 1: 50-60 & Factor 1: $0.02^{*}$ & Factor 1: $58-60$ & Factor 1: 0.92 \\
\hline & & Factor 2: $28,32,36$ & Factor 2: 0.24 & Factor 2: $28,32,36$ & Factor 2: $<0.01^{*}$ & Factor 2: $36-45$ & Factor 2: 0.85 \\
\hline & & Factor 3: 45,48 & Factor 3: 0.52 & Factor 3: 45,48 & Factor 3: $<0.01^{*}$ & Factor 3: 50-52 & Factor 3: 0.13 \\
\hline & & & & & & Factor $4: 28,32,58$ & Factor 4: 0.72 \\
\hline & \multirow[t]{3}{*}{$\lg M$} & Factor $1: 37,48,55,70$ & Factor 1: 0.74 & Factor $1: 37,48,55,70$ & Factor 1: 0.82 & Factor $1: 63,68,130$ & Factor 1: $0.01^{*}$ \\
\hline & & Factor 2: 63,68 & Factor 2: $0.03^{*}$ & Factor 2: 63,68 & Factor 2: 0.32 & Factor 2: $37,48,70$ & Factor 2: 0.92 \\
\hline & & Factor 3: 130 & Factor 3: $0.04^{*}$ & Factor 3: 130 & Factor 3: 0.66 & Factor 3: 55 & Factor 3: 0.62 \\
\hline \multirow[t]{6}{*}{ HMVEC-I } & \multirow[t]{3}{*}{$\lg G$} & Factor $1: 37,40,44,68$ & Factor $1:<0.01^{*}$ & Factor $1: 37,40,44,68$ & Factor $1:<0.01^{*}$ & Factor $1: 28,37,55$ & Factor 1: 0.32 \\
\hline & & Factor $2: 75,77$ & Factor 2: 0.19 & Factor $2: 75,77$ & Factor 2: 0.44 & Factor 2: $68,75,77$ & Factor 2: 0.16 \\
\hline & & Factor 3: $44,55,58,63$ & Factor 3: $<0.01^{*}$ & Factor 3: 58,63 & Factor 3: 0.82 & Factor 3: 40, 44, 63 & Factor 3: 0.1 \\
\hline & \multirow[t]{3}{*}{$\lg M$} & Factor $1: 32,48,65,80$ & Factor 1: 0.97 & Factor $1: 32,48,65,80$ & Factor 1: 0.79 & Factor 1: $58,90,100,110$ & Factor 1: 0.37 \\
\hline & & Factor 2: $58,80,90$ & Factor 2: 0.69 & Factor 2: $58,80,90$ & Factor 2: 0.98 & $\begin{array}{l}\text { Factor 2: } 32,48,65,78, \\
80\end{array}$ & Factor 2: 0.92 \\
\hline & & Factor 3: 100, 110 & Factor 3: 0.4 & Factor 3: 100, 110 & Factor 3: 0.55 & & \\
\hline \multirow[t]{5}{*}{ HMVEC-d } & \multirow[t]{3}{*}{$\lg G$} & Factor 1: $28-45$ & Factor $1:<0.01^{*}$ & Factor 1: 32-45 & Factor $1:<0.01^{*}$ & Factor 1: $28-45,58$ & Factor 1: 0.37 \\
\hline & & Factor 2: $58,63,100$ & Factor 2: $<0.01^{*}$ & Factor 2: 75,85 & Factor 2: $0.02^{*}$ & Factor 2: 63,85 & Factor 2: 0.66 \\
\hline & & Factor $3: 75,85$ & Factor 3: $0.03^{*}$ & Factor 3: $28,58,63$ & Factor 3: $<0.01^{*}$ & Factor 3: 75,100 & Factor 3: 0.49 \\
\hline & \multirow[t]{2}{*}{$\lg M$} & Factor 1: $38-43,55,90$ & Factor 1: 0.63 & Factor $1: 38-43,55,90$ & Factor 1: 0.74 & Factor 1: $38-43,55,90$ & Factor 1: 0.69 \\
\hline & & Factor 2: 73-77 & Factor 2: 0.36 & Factor 2: 73-77 & Factor 2: 0.36 & Factor 2: 73-77 & Factor 2: 0.92 \\
\hline \multirow[t]{7}{*}{ HEp-2 } & \multirow[t]{4}{*}{$\lg G$} & Factor 1: $27,31,32$ & Factor $1:<0.01^{*}$ & Factor 1: $27,31,36$ & Factor 1: $0.01^{*}$ & Factor 1: $28,36,45,75$ & Factor $1: 0.16$ \\
\hline & & Factor 2: 58,62 & Factor 2: $0.03^{\star}$ & Factor 2: 58,62 & Factor 2: 0.44 & Factor 2: 27,32 & Factor 2: 0.37 \\
\hline & & Factor 3: 28,45 & Factor 3: 0.5 & Factor 3: 28,45 & Factor 3: 0.84 & Factor 3: 28,45 & Factor 3: $<0.01^{*}$ \\
\hline & & Factor 4: 100 & Factor 4: $0.02^{*}$ & Factor $4: 32,75,100$ & Factor 4: $<0.01^{*}$ & Factor 4: 100 & Factor 4: 0.77 \\
\hline & \multirow[t]{3}{*}{$\lg M$} & Factor $1: 32,45,50,73,75$ & Factor 1: 0.1 & Factor $1: 32,45,50,73,75$ & Factor 1: 0.06 & Factor $1: 55,65,68,75$ & Factor 1: 0.37 \\
\hline & & Factor 2: $55,65,68$ & Factor 2: 0.27 & Factor 2: 25,28 & Factor 2: 0.24 & $\begin{array}{l}\text { Factor 2: } 25,28,32,45 \\
50,73,75\end{array}$ & Factor 2: 0.85 \\
\hline & & Factor 3: 25, 28 & Factor 3: 0.63 & Factor 3: 55,65 & Factor 3: 0.23 & & \\
\hline
\end{tabular}

For definition of abbreviations see footnote to table 2 .

*Level of significance of the comparison of the factor scores of patients with controls (paired Wilcoxon test).

Table 4 Comparison of factor scores of serum anti-endothelial and anti-HEp- 2 cell $\lg G$ and $\lg M$ reactivities from IPAH patients and SSc patients with or without PAH

\begin{tabular}{|c|c|c|c|c|c|}
\hline \multirow[b]{2}{*}{ Antigen sources } & \multirow[b]{2}{*}{ Isotype } & \multicolumn{2}{|l|}{ SSc-PAH v IPAH } & \multicolumn{2}{|l|}{ SSc-PAH v SSc without PAH } \\
\hline & & $\begin{array}{l}\text { MW of bands contributing } \\
\text { to factors }(\mathrm{kDa})\end{array}$ & $p$ value & $\begin{array}{l}M W \text { of bands contributing } \\
\text { to factors }(\mathrm{kDa})\end{array}$ & p value \\
\hline HUVEC & $\begin{array}{l}\lg G \\
\lg M\end{array}$ & $\begin{array}{l}\text { Factor 1: } 32,50-60 \\
\text { Factor 2: } 36,45 \\
\text { Factor 3: } 28,50,52 \\
\text { Factor 1: } 48,55,70 \\
\text { Factor 2: } 37,63,68 \\
\text { Factor 3: } 130\end{array}$ & $\begin{array}{l}\text { Factor 1: } 0.18 \\
\text { Factor 2: } 0.75 \\
\text { Factor 3: } 0.56 \\
\text { Factor 1: } 0.71 \\
\text { Factor 2: } 0.05 \\
\text { Factor 3: } 0.07\end{array}$ & $\begin{array}{l}\text { Factor 1: } 28,32,50-57 \\
\text { Factor 2: } 36,45 \\
\text { Factor 3: } 52,60 \\
\text { Factor 1: } 48,55,70 \\
\text { Factor 2: } 63,68 \\
\text { Factor 3: } 130\end{array}$ & $\begin{array}{l}\text { Factor 1: } 0.41 \\
\text { Factor 2: } 0.58 \\
\text { Factor 3: } 0.09 \\
\text { Factor 1: } 0.98 \\
\text { Factor 2: } 0.13 \\
\text { Factor 3: }<0.01 \text { * }\end{array}$ \\
\hline HMVEC-I & $\begin{array}{l}\lg G \\
\lg M\end{array}$ & $\begin{array}{l}\text { Factor 1: } 37,40,44 \\
\text { Factor 2: } 63,75,77 \\
\text { Factor 3: } 28,68 \\
\text { Factor 4: } 55,58 \\
\text { Factor 1: } 57,80,90 \\
\text { Factor 2: } 32,48,65 \\
\text { Factor 3: } 100,110\end{array}$ & $\begin{array}{l}\text { Factor 1: } 0.58 \\
\text { Factor 2: } 0.35 \\
\text { Factor 3: } 0.26 \\
\text { Factor } 4: 0.08 \\
\text { Factor 1: } 0.11 \\
\text { Factor 2: } 0.97 \\
\text { Factor 3: } 0.12\end{array}$ & $\begin{array}{l}\text { Factor 1: } 28,37,55,58 \\
\text { Factor 2: } 63,75,77 \\
\text { Factor 3: } 28,68 \\
\text { Factor 4: } 55,58 \\
\text { Factor 1: } 48,65 \\
\text { Factor 2: } 32,78,80 \\
\text { Factor 3: } 58,90,100,110\end{array}$ & $\begin{array}{l}\text { Factor 1: } 0.81 \\
\text { Factor 2: } 0.15 \\
\text { Factor 3: } 0.61 \\
\text { Factor 4: } 0.71 \\
\text { Factor 1: } 0.18 \\
\text { Factor 2: } 0.98 \\
\text { Factor 3: } 0.81\end{array}$ \\
\hline HMVEC-d & $\lg M$ & $\begin{array}{l}\text { Factor } 1: 32-45 \\
\text { Factor 2: } 28,32,63 \\
\text { Factor 3: } 75,85 \\
\text { Factor } 4: 58,100 \\
\text { Factor 1: } 38-43,55,90 \\
\text { Factor 2: } 73-77\end{array}$ & $\begin{array}{l}\text { Factor 1: } 0.82 \\
\text { Factor 2: } 0.36 \\
\text { Factor 3: } 0.33 \\
\text { Factor } 4:<0.01^{*} \\
\text { Factor 1: } 0.58 \\
\text { Factor 2: } 0.82\end{array}$ & $\begin{array}{l}\text { Factor 1: } 38-43,90 \\
\text { Factor 2: } 73-77 \\
\text { Factor 3: } 55\end{array}$ & $\begin{array}{l}\text { Factor 1: } 0.02^{*} \\
\text { Factor 2: } 0.71 \\
\text { Factor 1: } 0.18 \\
\text { Factor 2: } 0.47 \\
\text { Factor 3: } 0.3\end{array}$ \\
\hline HEp-2 & $\lg M$ & $\begin{array}{l}\text { Factor 1: } 28,36,45,75 \\
\text { Factor 2: } 58,62 \\
\text { Factor 3: } 27,31 \\
\text { Factor } 4: 100 \\
\text { Factor 1: } 32,45,50,73,75 \\
\text { Factor 2: } 65,68 \\
\text { Factor 3: } 25,28,55\end{array}$ & $\begin{array}{l}\text { Factor 1: } 0.21 \\
\text { Factor 2: } 0.02^{*} \\
\text { Factor 3: } 0.90 \\
\text { Factor } 4: 0.58 \\
\text { Factor 1: } 0.78 \\
\text { Factor 2: } 0.5 \\
\text { Factor 3: } 0.8\end{array}$ & $\begin{array}{l}\text { Factor 1: } 27,58,62,75,100 \\
\text { Factor 2: } 28,31,36,45 \\
\text { Factor 3: } 32 \\
\text { Factor 1: } 25,28,45,50,55 \\
\text { Factor 2: } 65,68 \\
\text { Factor 3: } 73,77\end{array}$ & $\begin{array}{l}\text { Factor 1: } 0.49 \\
\text { Factor 2: } 0.26 \\
\text { Factor 3: } 0.98 \\
\text { Factor 1: } 0.95 \\
\text { Factor 2: } 0.61 \\
\text { Factor 3: } 0.09\end{array}$ \\
\hline
\end{tabular}

For definition of abbreviations see footnote to table 2 .

*Level of significance of the comparison of the factor scores of patients with controls (Mann-Whitney test). 
Table 5 Serum IgM reactivities of patients with IPAH, SSc with or without PAH, and healthy individuals with endothelial cell antigens

\begin{tabular}{|c|c|c|c|}
\hline Patient groups/antigen sources & HUVEC & HMVEC-d & HMVEC-I \\
\hline \multicolumn{4}{|l|}{ Healthy individuals } \\
\hline No of reactivity peaks & $4-6$ & $11-13$ & $9-11$ \\
\hline \multirow[t]{4}{*}{ Main reactivities (no of individuals) } & $55 \mathrm{kDa}(25 / 65)$ & $38 \mathrm{kDa}(41 / 65)$ & $32 \mathrm{kDa}(50 / 65)$ \\
\hline & $63 \mathrm{kDa}(37 / 65)$ & $55 \mathrm{kDa}(65 / 65)$ & $48 \mathrm{kDa}(55 / 65$ \\
\hline & & $90 \mathrm{kDa}(25 / 65)$ & $65 \mathrm{kDa}(65 / 65))$ \\
\hline & & & $90 \mathrm{kDa}(30 / 65)$ \\
\hline \multicolumn{4}{|l|}{ IPAH } \\
\hline No of reactivity peaks & $4-6$ & $8-10$ & $10-12$ \\
\hline \multirow[t]{5}{*}{ Main reactivities (no of patients) } & $55 \mathrm{kDa}(14 / 35)$ & $38 \mathrm{kDa}(25 / 35)$ & $32 \mathrm{kDa}(20 / 35)$ \\
\hline & $63 \mathrm{kDa}(18 / 35)$ & $50 \mathrm{kDa}(24 / 35)$ & $48 \mathrm{kDa}(32 / 35)$ \\
\hline & & $55 \mathrm{kDa}(35 / 35)$ & $57 \mathrm{kDa}(28 / 35)$ \\
\hline & & $63 \mathrm{kDa}(13 / 35)$ & $65 \mathrm{kDa}(35 / 35)$ \\
\hline & & $90 \mathrm{kDa}(16 / 35)$ & $90 \mathrm{kDa}(10 / 35$ \\
\hline \multicolumn{4}{|l|}{ SSc with PAH } \\
\hline No of reactivity peaks & $4-6$ & $8-10$ & $8-10$ \\
\hline \multirow[t]{4}{*}{ Main reactivities (no of patients) } & $55 \mathrm{kDa}(4 / 10)$ & $27 \mathrm{kDa}(5 / 10)$ & $32 \mathrm{kDa}(8 / 10)$ \\
\hline & $63 \mathrm{kDa}(5 / 10)$ & 38 kDa (9/10) & $48 \mathrm{kDa}(8 / 10)$ \\
\hline & & $55 \mathrm{kDa}(10 / 10)$ & $57 \mathrm{kDa}(5 / 10)$ \\
\hline & & & $65 \mathrm{kDa}(9 / 10)$ \\
\hline \multicolumn{4}{|l|}{ Limited cutaneous SSc without PAH } \\
\hline No of reactivity peaks & $4-6$ & $9-11$ & $8-12$ \\
\hline \multirow{3}{*}{ Main reactivities (no of patients) } & $55 \mathrm{kDa}(7 / 10)$ & $38 \mathrm{kDa}(10 / 10)$ & 32 kDa $(8 / 10)$ \\
\hline & $63 \mathrm{kDa}(8 / 10)$ & $55 \mathrm{kDa}(10 / 10)$ & $48 \mathrm{kDa}(10 / 10)$ \\
\hline & & $90 \mathrm{kDa}(10 / 10)$ & $65 \mathrm{kDa}(9 / 10)$ \\
\hline \multicolumn{4}{|l|}{ Diffuse SSc without PAH } \\
\hline No of reactivity peaks & $4-6$ & $9-11$ & $10-12$ \\
\hline \multirow[t]{4}{*}{ Main reactivities (no of patients) } & $55 \mathrm{kDa}(8 / 10)$ & 38 kDa (5/10) & $32 \mathrm{kDa}(5 / 10)$ \\
\hline & $63 \mathrm{kDa}(6 / 10)$ & $55 \mathrm{kDa}(10 / 10)$ & $48 \mathrm{kDa}(9 / 10)$ \\
\hline & & 80 kDa $(5 / 10)$ & $65 \mathrm{kDa}(1010)$ \\
\hline & & 90 kDa (5/10) & \\
\hline
\end{tabular}

For definition of abbreviations see footnote to table 2 .

\section{DISCUSSION}

In this study we found that patients with IPAH express specific patterns of IgG reactivity with HUVEC, HMVEC-d and, to a lesser degree, with HMVEC-l and HEp-2 cell antigens, whereas IgG antibodies from patients with SSc with or without PAH bind to HMVEC-d, HMVEC-l and HEp-2 cell proteins but not to HUVEC proteins, although the difference did not reach significance.

To our knowledge, AECA have not been detected previously in patients with IPAH. In many patients with PAH disorganised proliferation of endothelial cells is observed, leading to the formation of plexiform lesions. ${ }^{16}$ Endothelial dysfunction leads to chronically impaired production of vasodilators, nitric oxide, and prostacyclin, together with overexpression of vasoconstrictors such as endothelin-l, resulting in the narrowing of the pulmonary arterial lumen and endothelial cell proliferation. Stimuli known to promote abnormal endothelial proliferation include hypoxia, shear stress, inflammation, and response to drugs or toxins in genetically susceptible individuals.

AECA have been detected in SSc patients with limited cutaneous or diffuse SSc, ${ }^{7-9}$ particularly in patients with vascular manifestations such as $\mathrm{PAH}$ and digital ischaemia9 ${ }^{10}$ and in patients with pulmonary fibrosis. ${ }^{17}$ Using a systematic approach, we have recently shown that IgG antibodies from patients with limited cutaneous or diffuse SSc, with or without anti-topoisomerase 1 antibodies, exhibit specific and mutually exclusive reactivity patterns. ${ }^{11}$ These results led us to speculate that autoantibodies from these SSc patients specifically bind to different types of endothelial cells and support the classification of AECA according to disease specific target endothelial cells proposed by Praprotnik et al. ${ }^{18}$

AECA target antigens comprise a wide range of extracellular matrix proteins ${ }^{19}$ and molecules that adhere to endothelial cells, such as DNA in systemic lupus erythematosus, ${ }^{20} \beta_{2}$-glycoprotein I or phospholipids ${ }^{21}$ in anti-phospholipid syndrome, myeloperoxidase ${ }^{22}$ or proteinase $3^{23}$ in primary systemic vasculitides, and $\alpha$-enolase in Behcet's disease. ${ }^{24}$ Until recently, in patients with SSc none of the AECA target antigens had been identified but some molecular weights have been determined. Ihn et al ${ }^{17}$ found that AECA from patients with SSc bind to target cytoplasmic antigens of $60,90,110$, and $140 \mathrm{kDa} .{ }^{17}$ Hill et al reported that antibodies directed to a $19 \mathrm{kDa}$ protein, associated with limited cutaneous SSc, expressed anti-centromere activity. This observation led them to postulate that these AECA might trigger inflammation of endothelial cells in connective tissue diseases. ${ }^{825}$ Finally, we recently identified DNA topoisomerase 1 as a $100 \mathrm{kDa}$ endothelial cell target for IgG antibodies from patients known to express anti-topoisomerase 1 antibodies as assessed by other techniques. ${ }^{11}$ In a recent study IgG AECA from patients with diffuse SSc consistently recognised HMVEC-d but only 50\% of them bound to HUVEC. ${ }^{26}$

Very few studies are available in the literature regarding the antigens specifically expressed by endothelial cells. To our knowledge, the only published proteomic analysis of human endothelial cells focused on quiescent HUVEC and identified 53 proteins of suspected endothelial origin. ${ }^{27}$ In addition to cytoskeleton proteins, proteins involved in cellular mobility, regulation of apoptosis, and senescence have been identified, as well as proteins implicated in clotting or antigen presentation, but we could not find any data on the characterisation of microvascular specific endothelial cell antigens. Our results lead us to infer that some endothelial cell antigens are expressed by microvascular endothelial cells and others such as HEp-2 cells, but not by macrovascular endothelial cells. 
Reactivities detected by immunoblotting reflect the specific binding of the various regions of IgM and IgG antibodies to tissue antigens. ${ }^{28}$ Since the profiles of reactivity were homogeneous among patients in each group and in healthy controls, despite the use of the same endothelial cell sources to test all patients, it is highly improbable that these reactivities reflect alloreactivities.

This study provides evidence, for the first time, that patients with IPAH and PAH associated with SSc express AECA. The target antigens and the potential pathogenetic role of these antibodies remain to be determined. The predictive value of these antibodies in patients at risk of developing $\mathrm{PAH}$, such as SSc patients and those with a familial history of PAH, needs to be investigated.

\section{ACKNOWLEDGEMENTS}

The authors thank Dr Frédéric Batteux who provided the HEp-2 cells and Dr Michèle Uzan who provided normal human umbilical cords.

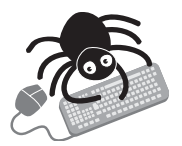

Densitometric profiles of IgG reactivities with HEp-2 cells and IgM reactivities with endothelial cells are shown in figs S1 and S2 available on the Thorax website at http://www.thoraxinl.com/supplemental.

\section{Authors' affiliations}

M C Tamby, Y Chanseaud, P Guilpain, P Garcia-de-la-Peña-Lefebvre, S Brunet, M C Boissier, L Mouthon, UPRES-EA 3408, Laboratoire d'Immunopathologie et Immuno-intervention, UFR-SMBH Léonard de Vinci, Université Paris Nord, Bobigny, France

M C Tamby, Y Chanseaud, P Guilpain, A Servettaz, B. Weill, L Mouthon, UPRES-EA 1833, Laboratoire d'Immunologie, UFR CochinPort Royal, Université Paris V, Paris, France

M Humbert, G Simonneau, UPRES-EA 2705, Service de Pneumologie, Hôpital Antoine Béclère, Assistance Publique-Hôpitaux de Paris (AP-HP) et Université Paris Sud, Clamart, France

J Fermanian, Service de Biostatistiques, Hôpital Necker, AP-HP, Université Paris V, Paris, France

L Guillevin, L Mouthon, Service de Médecine Interne, Hôpital Cochin, AP-HP et Université Paris V, Paris, France

This work is supported by a grant from the Universite Paris Nord (Bonus Qualité Recherche), INSERM (CReS \#4CR08F), the Association des Sclérodermiques de France and the Legs POIX, Chancellerie des Universités, Académie de Paris, France. The study was supported in part by the French Network of Pulmonary Arterial Hypertension. M C Tamby is a recipient of a grant from AMPLI (Avenir Mutualiste des Professions Libérales \& Indépendantes); Y Chanseaud was funded by the Ministère de l'Enseignement Supérieur et de la Recherche, France and the Laboratoire Français du Fractionnement et des Biotechnologies (LFB); P Garcia de la Peña-Lefebvre received a grant from the Association Claude-Bernard, France; A Servettaz received financial support from the Direction Régionale de l'Action Sanitaire et Sociale de la région Champagne-Ardennes, France.

Competing interests: none declared.

This work has been presented at the 3rd Annual Meeting of the Federation of Clinical Immunology Societies (FOCIS), 15-19 May 2003, Paris, France; at the 4th Annual Congress of the European League Against Rheumatism (EULAR), 19-21 June 2003, Lisbon, Portugal; and at the 67th ACR/ARHP Annual Scientific Meeting, 24-28 October 2003, Orlando, Florida, USA.

\section{REFERENCES}

1 Rubin L. Primary pulmonary hypertension. N Engl J Med 1997;336:111-7.

2 Dorfmuller $\mathbf{P}$, Perros F, Balabanian K, et al. Inflammation in pulmonary arterial hypertension. Eur Respir J 2003;22:358-63.
3 Mukeriee D, St George D, Coleiro B, et al. Prevalence and outcome in systemic sclerosis associated pulmonary arterial hypertension: application of a registry approach. Ann Rheum Dis 2003;62:1088-93.

4 Lane KB, Machado RD, Pauciulo MW, et al. Heterozygous germline mutations in BMPR2, encoding a TGF-beta receptor, cause familial primary pulmonary hypertension. The International PPH Consortium. Nat Genet 2000;26:81-4

5 Trembath RC, Thomson JR, Machado RD, et al. Clinical and molecular genetic features of pulmonary hypertension in patients with hereditary hemorrhagic telangiectasia. N Engl J Med 2001;345:325-34

6 Morse J, Barst R, Horn E, et al. Pulmonary hypertension in scleroderma spectrum of disease: lack of bone morphogenetic protein receptor 2 mutations. $J$ Rheumatol 2002;29:2379-81

7 Rosenbaum J, Pottinger BE, Woo $P$, et al. Measurement and characterisation of circulating anti-endothelial cell lgG in connective tissue diseases. Clin Exp Immunol 1988;72:450-6.

8 Hill MB, Phipps JL, Cartwright RJ, et al. Antibodies to membranes of endothelial cells and fibroblasts in scleroderma. Clin Exp Immunol 1996:106:491-7.

9 Salojin KV, Le Tonqueze M, Saraux A, et al. Antiendothelial cell antibodies: useful markers of systemic sclerosis. Am J Med 1997;102:178-85.

10 Negi VS, Tripathy NK, Misra R, et al. Antiendothelial cell antibodies in scleroderma correlate with severe digital ischemia and pulmonary arterial hypertension. J Rheumatol 1998;25:462-6.

11 Garcia de la Pena-Lefebvre $P$, Chanseaud Y, Tamby MC, et al. IgG reactivity with a 100-kDa tissue and endothelial cell antigen identified as topoisomerase 1 distinguishes between limited and diffuse systemic sclerosis patients. Clin Immunol 2004;111:241-51.

12 LeRoy EC, Medsger TA Jr. Criteria for the classification of early systemic sclerosis. J Rheumatol 2001;28:1573-6.

13 Masi AT, Rodnan GP, Medsger TA, et al. Preliminary criteria for the classification of systemic sclerosis (scleroderma). Arthritis Rheum 1980;23:581-90.

14 Chanseaud Y, Pena-Lefebvre PG, Guilpain P, et al. IgM and $\lg G$ autoantibodies from microscopic polyangiitis patients but not those with other small- and medium-sized vessel vasculitides recognize multiple endothelial cell antigens. Clin Immunol 2003;109:165-78.

15 Harman HH. Modern factor analysis, 2nd edn. Chicago: The University Of Chicago Press, 1967

16 Voelkel N, Tuder R, Weir E. Pathophysiology of primary pulmonary hypertension from physiology to molecular mechanisms. In: Rubin L, Rich S, eds. Primary pulmonary hypertension. New York: Marcel Dekker, 1997:83-129.

17 Ihn H, Sato S, Fujimoto $M$, et al. Characterization of autoantibodies to endothelial cells in systemic sclerosis (SSc): association with pulmonary fibrosis. Clin Exp Immunol 2000;1 19:203-9.

18 Praprotnik S, Blank M, Meroni PL, et al. Classification of anti-endothelial cell antibodies into antibodies against microvascular and macrovascular endothelial cells: the pathogenic and diagnostic implications. Arthritis Rheum 2001;44:1484-94.

19 Direskeneli H, D'Cruz D, Khamashta MA, et al. Autoantibodies against endothelial cells, extracellular matrix, and human collagen type IV in patients with systemic vasculitis. Clin Immunol Immunopathol 1994;70:206-10.

20 Chan TM, Frampton G, Staines NA, et al. Different mechanisms by which antiDNA MoAbs bind to human endothelial cells and glomerular mesangial cells. Clin Exp Immunol 1992;88:68-74.

21 Del Papa N, Sheng YH, Raschi E, et al. Human beta 2-glycoprotein I binds to endothelial cells through a cluster of lysine residues that are critical for anionic phospholipid binding and offers epitopes for anti-beta 2-glycoprotein I antibodies. J Immunol 1998; 160:5572-8.

22 Savage CO, Gaskin G, Pusey CD, et al. Anti-neutrophil cytoplasm antibodies can recognize vascular endothelial cell-bound anti-neutrophil cytoplasm antibody-associated autoantigens. Exp Nephrol 1993;1:190-5.

23 de Bandt M, Benali K, Guillevin L, et al. Longitudinal determination of antiphospholipid antibodies in lupus patients without previous manifestations of antiphospholipid syndrome. A prospective study. J Rheumatol 1999:26:91-6.

24 Lee KH, Chung HS, Kim HS, et al. Human alpha-enolase from endothelial cells as a target antigen of anti-endothelial cell antibody in Behcet's disease. Arthritis Rheum 2003:48:2025-35.

25 Okawa-Takatsuji M, Aotsuka S, Fujinami M, et al. Up-regulation of intercellular adhesion molecule-1 (ICAM-1), endothelial leucocyte adhesion molecule-1 (ELAM-1) and class II MHC molecules on pulmonary artery endothelial cells by antibodies against U1-ribonucleoprotein. Clin Exp Immunol 1999:116:174-80.

26 Sgonc R, Gruschwitz M, Boeck G, et al. Endothelial cell apoptosis in systemic sclerosis is induced by antibody-dependent cell-mediated cytotoxicity via CD95. Arthritis Rheum 2000;43:2550-62.

27 Bruneel A, Labas V, Mailloux A, et al. Proteomic study of human umbilical vein endothelial cells in culture. Proteomics 2003;3:714-23.

28 Mouthon L, Nobrega A, Nicolas N, et al. Invariance and restriction towards a limited set of self-antigens characterize neonatal IgM antibody repertoires and prevail in autoreactive repertoires of healthy adults. Proc Natl Acad Sc USA 1995:92:3839-43. 